\title{
'BE GRACEFUL, PATIENT, EVER PRAYERFUL': NEGOTIATING FEMININITY, RESPECT AND THE RELIGIOUS SELF IN A NIGERIAN BEAUTY PAGEANT
}

\author{
Juliet Gilbert
}

11 p.m. The lights came up, the expectant audience hushed, and thirty contestants strode out purposefully onto the stage to the beat of Beyoncé's Single Ladies. In short gold sequined dresses, red high heels and matching red hairpieces, they looked identical. As the contestants assembled themselves alphabetically according to their blue sashes, each depicting a Cross River tourist site, the former queens walked on behind them. In the seldom-used Nollywood studio on the edge of Calabar, the competition to find the Carnival Calabar Queen 2011 had begun. One of the most popular carnival events, which transforms Cross River's capital each December, the evening marked the crowning of a new queen, ambassador for state tourism and the First Lady's charitable initiatives.

Completing certain tasks, the contestants proved they had the necessary qualities to win the crown. The first individual walk down the catwalk demonstrated each girl's poise. A 'profile video' played on screens to the side of the stage, introducing the contestants: their sash name, their own name, their university and subject studied, and their hobbies - typically acting, singing, travelling, dancing and volunteering, but also 'taking photos of myself'. The contestants' characters were examined further by their second costume: 'traditional attire' - made, and explained on stage, by each contestant. Many chose the maiden's costume from their villages, while some chose the local Efik dress to impress the judges. While this costume highlighted contestants' cultural knowledge, the final costume long evening gowns made especially for the contest by Vlisco, the highly sought-after Dutch wax fabric - highlighted another aspect of the ideal Nigerian young woman: class.

The judges - popular figures in the Nigerian media, and on this occasion a former queen - chose the top ten for the next stage: the showcasing of talents. Popular talents were singing, acting and public speaking, with the contestants choosing to theme their act around the issues of womanhood and HIV awareness (issues linked to Her Excellency's office). From these talents, the top five were picked and each posed one question: if you found out you had just one week to live, what would you do? Who would you choose for the Nobel Peace prize? Can you briefly describe your experience of the contest so far? If you win, what would you do with the car? If the judges were stuck in a burning building, who would you save?

JULIET GilberT is currently a Teaching Fellow in the Department of African Studies and Anthropology at the University of Birmingham. Her research examines young women's aspirations and strategies for becoming successful in Calabar, Nigeria. Her main interests are youth, Christianity (especially Pentecostalism), uncertainty and popular culture (particularly fashion, beauty and mobile phones). Email: J.Gilbert.2@bham.ac.uk 
At 3 a.m., as the judges made their choices, the First Lady came to the stage. Explaining her work, she told how she was carrying out God's vision. As we had been told earlier in the evening, the pageant was a 'divine initiative', borne out of emotion. It was Her Excellency's love for the young and her pain at seeing their 'destinies cut short' that inspired her to create a pageant where a young woman could influence others. As the winner who would aid the First Lady's vision was announced, the outgoing queen paraded across the stage once more. Handing the crown to her successor, she advised: 'Be graceful, patient, ever-prayerful without ceasing.'

The spectacle of the contest night epitomizes pageantry, pinpointing power struggles in the production, consumption and rejection of cultural meanings. While literature remains sparse, the few analyses that do exist tend to focus on contests of power through their illumination of beauty pageants as sites for showcasing ideals of gender and the nation (for example, Banet-Weiser 1999; Cohen et al. 1996; Schulz 2000; Watson and Martin 2004). A community's ideals, morals and values are made visible on the pageant stage and reified by the winning contestant, the crowned community representative. Yet, as these values are revealed, they are also opened up to challenges and reinterpretation by others. Hence, while pageants put forth the notion of a standard ideal of beauty, they also raise questions as to who decides this ideal and how it is maintained. As Cohen et al. note: 'Struggles over beauty contests are also struggles over the power to control and contain the meaning mapped on the bodies of competitors' (1996: 9).

Feminist debates have picked up on how pageantry construes and represents gendered ideals. For instance, church groups and women's rights lobbyists have attacked the Miss America pageant since its conception in the 1920s. While the 1968 protest against the pageant exemplified feminist discourse of the time women as sexualized commodities - subsequent condemnations raised issues of race and body image (cf. Banet-Weiser 1999; Cohen et al. 1996; Douglas 1994; Sanders and Pink 1996). Yet, against this feminist critique, beauty pageants remain popular spectacles for creating community representatives and have found an appeal in countries beyond the US - not least in Nigeria. For instance, Miss Nigeria, which was started as a photographic competition in the Daily Times in 1957, and Most Beautiful Girl in Nigeria (MBGN) create ambassadors for the nation, sending their winners to compete in international contests such as Miss Universe. The fascination with pageant queens has also spread to state and local governments, commercial enterprises (Glo Mobile's Miss Rock 'N' Rule), universities (and National Youth Service Corps camps), churches (Miss PowerCity Church, Calabar), community events (Miss Leboku for Yakurr's New Yam Festival), and societal causes (Face of Amnesty, a cause for Niger Delta militants). The Nigerian media is awash with queens' worthy actions. While pageantry scandals are also well documented, these tend to comment on the winner's failure to perform a certain feminine ideal rather than be critiques of pageantry per se.

In understanding how pageants such as the Carnival Calabar Queen gain and maintain such popularity in Nigeria, it is necessary for anthropological analyses to look to the local, both in acknowledging emic conceptions of beauty and in understanding how pageantry fits into local power structures. Writing about the production and consumption of Mali's popular Miss ORTM pageant, Schulz 
(2000) offers one useful analysis to help us draw out the nuances of power, gender and the nation in African pageantry. Since Miss ORTM was first broadcast on national television, a small elite has driven ideals of Malian beauty that do not encompass the whole nation. Urban ideals of slim girls reminiscent of the 'Western' fashion industry ignore the majority of Mali women, and the pageant's preference for southern contestants arguably excludes Mali's northern triangle. Following Schulz's (2000) view of the global pageantry world through a local lens, this paper shows how (new) standards of beauty are not imposed by 'Western' culture but adopted and encouraged by certain groups at the local level for particular gains and outcomes. While Schulz frames pageantry as a vehicle for Malian governmental cultural politics, this paper pays attention to the way in which contestants use pageantry to enact the feminine ideals they hope will generate personal success.

In understanding how new feminine ideals are created, this paper sees the need to understand contestants' motivations for and experiences of pageantry, thereby complicating feminist critiques of pageantry as negating agency and presenting women as commodities. For instance, writing about the Minnesota Community Queen Pageant, Lavendo (1996) argues that pageantry has multiple, often contradictory, outcomes due to both organizers' widely divergent inspiration and contestants' varying interpretations of the competition. While contestants are chosen and sponsored by a small business community, Lavendo (1996: 45) argues that we should not dismiss contestants' 'imaginative agency' in their participation. Also noting contestants' motivations, Moskalenko's (1996) reflective piece on winning Moscow Beauty 1989 places pageantry within the context of local politics. After Perestroika, Moscow Beauty opened up new avenues for how women were viewed in society. While organizers were looking for a typical Moscow beauty, Moskalenko (1996), a student at the time, describes how she was surrounded by pageant-goers united by one motivation: to be noticed and feel important. Unfortunately, while highlighting contestants' motivations, both authors fail to detail their experiences after pageantry, to show whether or not they benefited from their participation and wins.

Banet-Weiser (1999) offers a more persuasive argument for contestants' agency with her performative approach to understanding the production of gender in the Miss America pageant. For the author, gender is not just produced by dominant discourses but is actively (re)produced through the contestants' very performances, marked by their excessive make-up, honed bodies and disciplined deportment. Where the gendered body is a creation and enactment of power rather than a site of passivity on which power imposes itself (Foucault 1998), Banet-Weiser (1999) allows us to question male dominance in the pageantry world, transcending a simplistic relationship between women and commodities, and raising questions of why young women may want to compete in pageants. Seeing the merits of this analytical framework, the present paper focuses on performance in asking how ideal femininities are created in Nigerian pageantry, acknowledging contestants' agencies and exploring how young women are moulded throughout the pageantry process. However, where emic ideals of femininity are shown to support patriarchy, the discussion draws on ideas of resistance through the performance of (religious) gendered subjects (cf. Mahmood 2005) to complicate Banet-Weiser's (1999) ideas that female agency in pageantry necessarily overthrows male dominance. 
This paper examines how the Carnival Calabar Queen pageant (CCQ) is a site for producing a community's visions of ideal femininity. It argues that (new) feminine ideals are created through the constant performance of a certain cultural logic of feminine respectability - namely, caring and God-fearing - yet that such a performance, while demonstrating female agency, does not necessarily distance (young) women from Nigerian patriarchy. The paper draws on fifteen months of doctoral research undertaken in Calabar between 2010 and 2012. Although pageantry was not the primary focus of my research on young women's livelihoods, I was struck by how many of my informants were involved in it. Wanting to understand pageantry better, I participated in the CCQ 2011 and 2012 contests' two-week camps. Knowledge of CCQ and other pageants was furthered through interviews conducted throughout my fieldwork with organizers, contestants and winners.

The paper starts with an overview of CCQ's conception, highlighting how the creation of such gendered ideals is linked explicitly to local politics of power and visions of Christian respectability. The second section views the pageant camp as a rite of passage, detailing the acts that simultaneously mould young women in the setting of the contest's seclusion and allow them to re-enter society with a different status through their knowledge of a new gendered performance. The final section focuses on young women's experiences of pageantry. Developing current understandings of contestants' motivations for entering pageantry, the section reiterates the argument that the celebrated female figure is a constant performance of feminine respectability not necessarily removed from the linked constraints of patriarchy and insecurity that characterize life in Calabar.

\section{CARNIVAL CALABAR QUEEN AND CROSS RIVER STATE}

The quest to crown a Carnival Calabar Queen began in 2007. Senator Liyel Imoke had just been elected as Cross River's state governor, continuing the People's Democratic Party dream of creating a model state for Nigeria. Since 1999, the out-going state governor, Donald Duke, had spent lavishly. Projects such as Calabar Free Trade Zone at Tinapa business and leisure resort, Obudu Cattle Ranch and its International Mountain Race, and the annual Carnival Calabar sought to transport the quiet 'civil service state' from the backwaters of Nigeria onto the world stage. While some initiatives have had success - such as the carnival, which has been hailed as 'Africa's biggest street party' - many have suffered from a lack of investment and interest and now lie as empty vessels of potential. Although Cross River is distanced from the North's current Islamic insurgencies or the Delta's ongoing oil disputes, many Cross Riverians, including young women, recognize that living in such an idyll also brings a lack of opportunities compared with cities such as Lagos, Port Harcourt and Abuja.

Entering office against this backdrop, Senator Imoke emphasized helping society's most needy in his vision for Cross River. Imoke soon became known for his humility and will to serve his people. As a fervently Pentecostal woman, the First Lady, Her Excellency Obioma Imoke, saw it as her place to support her husband's mission and image, and founded initiatives such as POWER (Partnership Opportunities for Women Empowerment Realization) and asFac 
(A State Fit for a Child) to support Cross River's women and children. While Cross River is characterized as forward thinking, with the colloquial acronym 'Come And Live And Be At Rest' denoting the state's optimism, these initiatives highlight the harsh and uncertain reality many Nigerians endure (cf. Haram and Yamba 2009; Odabare and Adebanwi 2010).

Young women, one of society's most vulnerable groups, are targeted by another of Her Excellency's charities, MACA (Mothers Against Child Abandonment). MACA's exemplary story of the day-old baby's corpse found in a dustbin illustrates young women's struggles as they experience the double bind of gender and generation in Cross River's patriarchy and conservatism. As MACA recognizes, young women are seldom able to negotiate their rights. They face challenges from men, including strangers, family members and supposed lovers. Many, for example, are affected by sexual abuse and are unaware of the consequences of unprotected sex. Such challenges are mostly dealt with in silence, yet they are also heightened when unmarried girls fall pregnant. Aiming to enable marginalized young women to resume a normal life and remain respected in society after pregnancy, MACA offers support through two refuges: providing healthcare and skills workshops for the pregnant girls in one, and caring for the babies they are encouraged to give up in another.

MACA is able to help only a handful of young women directly, but it aims to reach out to others in Cross River through awareness programmes. Believing that girls would be more receptive to another young woman's advice, Her Excellency created a pageant to find an ambassador for her charitable work. The crowned winner, the Carnival Calabar Queen, plays a significant role as a peer educator, visiting schools and acting as a role model for Cross River's young women. She also mentors the refuge girls, acting as confidante and teaching them skills such as beading and baking. Explaining the efficacy of having queens as peer educators, one CCQ organizer said: '[The girls] are excited to see a queen ... Being a queen has a double advantage because it's like, "Oh, she's a queen and she will listen to us."

Imoke's pageant is an excellent lens through which to understand how young women experience the insecurities and inequalities of life in Nigeria, their challenges and successes of navigating life worlds governed by, as Mbembe (2001) asserts, male virility. Above all, CCQ allows us to question how some women can gain power, respect and success. Indeed, Obioma Imoke's support for her husband's administration through her charitable works speaks to Mama's (1995) analysis of the 'First Lady phenomenon'. Epitomized by Maryam Babangida, who started campaigning for women's rights after her husband won the Nigerian presidency in 1985, Mama argues that, far from experiencing discrimination and injustice (cf. Chazan 1989), these women use government resources to become activists for worthy causes in order to secure more power and votes. Mama's trope of 'femocracy' keeps female power within the remit of their husbands' administrations. Yet in understanding the complex image of the First Lady the inherent tensions of patronage and care - it is interesting to explore the ways in which she is able to secure power and respect from her supporters. We may draw on Imoke's own words to show her reasons for carrying out her charitable projects. At the centre of her charitable work is her love for God, her husband, and children. The First Lady embodies (Pentecostal) Christian understandings that it is the woman's role to pray for the family and nation. 
The way in which an elite woman gains support and emulates success by carrying out her Christian duties as a wife undoubtedly raises questions already asked in anthropology about gendered power relations in the performance of religious subjectivities. Problematizing our 'Western' conception that women's empowerment comes through gender equality, Soothill's (2007) analysis of Ghanaian Pentecostalism draws links between the supporting role of the spiritually strong wife and notions of West African gender complementarity (cf. Amadiume 1987). While Soothill (2007) claims that the performance of different gendered roles supports a productive relationship, Mate (2002) argues that Pentecostalism's emphasis on wives' roles as spiritual sustenance merely perpetuates men's political and social domination.

We may also look to analyses of Muslim women to better understand the complexities of women's lived experiences of patriarchy. For instance, focusing on women's involvement in Cairo's Muslim piety groups, Mahmood (2005) illustrates how choosing to learn how to act and desire in ways that accord with Islamic principles renders women subordinate to men but also highlights female agency. Central to our understanding of these gender dynamics are not only ideas of freedom, empowerment and agency, but also of resistance. For instance, Abu-Lughod's (1986; 1989) analyses of Bedouin women highlight the multiple devices - from poetry to delaying marriage - this group uses to simultaneously subvert and comply with patriarchal power. Similarly, Boddy's (1989) examination of the zar cult in northern Sudan depicts how women's bodies play host to spirits who act outside Islamic norms, allowing women to acknowledge their subordination and resist dominant discourses. While the lavish outfits and entourages of First Ladies, or even the figure-hugging outfits of Nigerian pageant contestants, are a far cry from Muslim women's modesty and concealment, these analyses call attention to the ways in which women choose to play certain roles in their respective cultures through (religious) action and styling the body. Recognizing multiple forms of resistance and structures of power (Abu-Lughod 1989: 53), such an analysis helps us go beyond Banet-Weiser's (1999) emphasis on performance to question whether female agency in pageantry always counters male dominance.

Rather than understanding how First Ladies empower themselves with charitable works through analyses of political relations and access to wealth (cf. Mama 1995), we therefore can recognize how First Ladies gain power by performing local visions of feminine success and respectability. Women carve out an arena of power for themselves by carrying out charitable works for the marginalized in society. Interestingly, just as the supportive female is not an outright rejection of patriarchy, nor does it ignore the way in which the state is run along the lines of 'deeply personalised political relations' (Chabal and Daloz 1999: 16). As this paper highlights throughout, networks of women are emerging whose power lies in their concern for the future of Nigeria. The outreach and resources of these elite networks of female patronage in Nigeria should not be underestimated: Sarah Brown, the wife of the former British prime minister, visited Her Excellency's initiatives in Calabar in June 2012 in connection with a partnership of youth empowerment.

The importance placed on the caring and spiritually strong female within a disordered environment in which patriarchy sometimes goes unchallenged also raises questions regarding development. Writing about non-governmental organization 


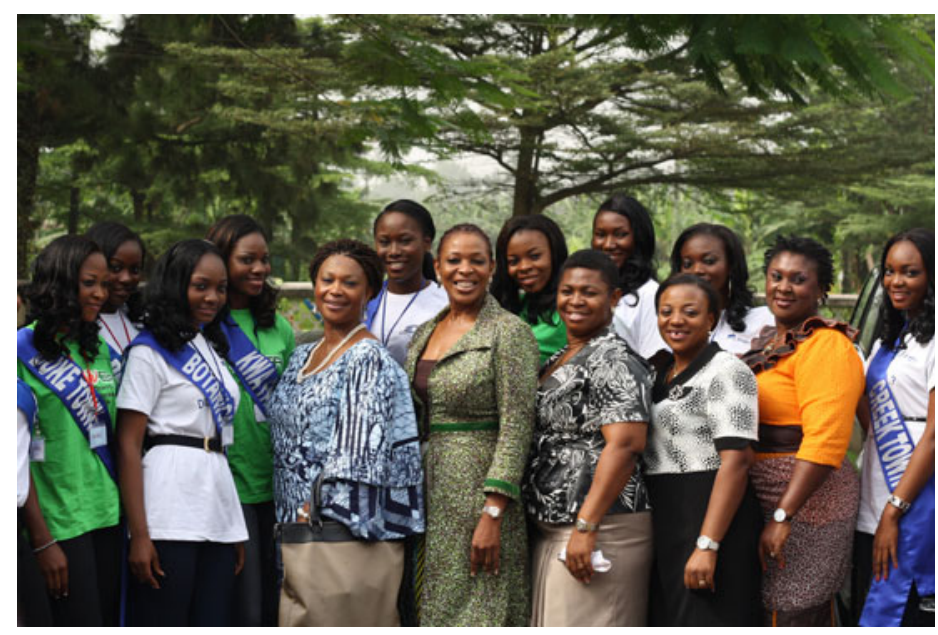

FIGURE 1 Her Excellency Obioma Imoke (fourth from left, front row) and the most senior members of her office pose with contestants during the CCQ camp, depicting the networks of female patronage girls hope to benefit from.

(NGO) workers in Ghana, Yarrow (2011) argues that, rather than African development articulating the hijacking of resources by elites or projects merely covering up deep societal inequalities, development organizations have become a pivotal part of African reality. Without delving too deeply into the accountability of where First Ladies' resources come from or how they are used, it is important to understand how Nigerians are coming to terms with and act upon their own realities. As women caring for both the nation's marginalized and its future are thanked and venerated by society, they become role models for younger women, eager to emulate the same success (see Figure 1). As one CCQ contestant stated: 'Our First Lady is like a visioner. She likes this whole NGO thing ... Seeing that the person who is at the head of affairs is really pushing this thing, we want to be recognized and to help her.'

Many young women I knew aspired to work in NGOs, studied social work, and spent their birthdays giving donations and cutting cake at orphanages. The value young women place on such work speaks of a complex dovetailing of philanthropic motives on the one hand, and the aspiration to enhance their status (and job prospects) on the other, especially in settings such as rural South Africa where gender and generational power cleavages constrain most other opportunities for advancement (James 2002; McNeill 2011). Africa's middle class is growing, and its status cannot be measured purely in terms of income level or consumerism (see, for example, Mercer 2014; Ncube et al. 2011). This class of urban young woman emerging in Calabar is defined, in part, by its members' involvement in the recognition of societal ills and their display of acts of care. Perhaps counterintuitively, their involvement in pageantry is one way of demonstrating these acts of care. Reminiscent of the Miss World formula of 'beauty with a purpose', Nigerian beauty queens' crowns and titles grant them the social (and economic) capital to carry out charitable projects. Young women perceive 
pageantry as a means of acquiring fame and success, and, equally, as a means to remove themselves from their own experiences living amid insecurity, patriarchy and gerontocracy. As one queen stated about winning a pageant: '[Society] will regard you, they know you have something to say.' With the ideal of the caring, spiritually strong woman at the centre of enquiry, this paper goes on to discuss how the CCQ pageant is a site for creating new femininities of respect and success - an arena of socialization that extends outwards from pageant-goers to those young women who are inspired by beauty queens. Focusing on performance, the discussion pays attention to female agency in understanding how young women may feel empowered when they seemingly remain bound by the patriarchal system that disadvantages them.

\section{'GRACE AND BEAUTY': THE PAGEANT CAMP}

Towards the end of the year, CCQ begins its advertising campaign. While a radio advertisement encourages girls to 'pick' a 5,000 naira ${ }^{1}$ form to be in with a chance of having a life-changing experience, organizers and former contestants post fliers on social media platforms such as Facebook to persuade others to enter. Auditions, which see some 100 girls compete for thirty places, are held in Calabar, Lagos and Abuja. CCQ requires entrants to be between eighteen and twenty-five years of age, single, a citizen of Nigeria, and a university student or graduate, and audition judges look for appearance, poise, knowledge of MACA and Cross River, and compassion and eloquence. All the contestants I knew were city-dwellers familiar with the physical, economic, political, social and spiritual insecurities of urban Nigerian life. It was often difficult to distinguish family backgrounds in view of girls' consistent ability to display a 'cultural knowledge of urban success' through their stylish clothes, comportment and care for others.

While literature focuses on how pageants are sites in which communities' ideals of feminine beauty are formed (Banet-Weiser 1999; Cohen et al. 1996), little attention has been paid to the ways in which camps mould new femininities. Leading up to the CCQ contest night, the two-week camp is central to the grooming process to find a queen and ambassador for MACA. Once the girls have arrived at Channelview, one of the most exclusive hotels in Calabar, the pageant's mantra of 'grace and beauty' plays out: contestants are made up and attend a two-day UNICEF workshop. After this, the girls move to Surefoot American International School (another of the First Lady's initiatives). In seclusion (and with BlackBerries confiscated), they rehearse acting, dancing and catwalking skills for the competition night. They also visit Calabar's tourist attractions and learn about Cross River and Her Excellency's initiatives. As a spectacle for the Carnival Calabar, the entire camp and contest are filmed by a production company, and later aired on local television and posted on internet sites.

In its socializing of young women, this fortnight can be viewed as a rite of passage as in van Gennep's (1960) classic anthropological account. In the camp environment, the contestants undergo isolation before their reinsertion into

\footnotetext{
${ }^{1}$ During my doctoral fieldwork in 2011 , the exchange rate was roughly 250 naira to the British pound.
} 
public society. The camp prepares the contestants, turning them into feminine subjects exuding success, beauty and respectability, thus conferring a new social status and altering the individual's relationship to the group (cf. van Gennep 1960: 5). As exemplified in the UNICEF conference, the whole camp is not concerned with just the contest finale, finding a winning contestant who exemplifies a certain ideal, but is also about moulding more long-term visions of respectable femininity. The twoday event is primarily an educative exercise, designed to equip the girls with facts about HIV and AIDS, sexually transmitted diseases, and the complications of pregnancy and abortion (illegal in Nigeria). In groups, contestants practise presentation, problem-solving and communication skills. The style and subject matter of such exercises, which address scenarios about teenage pregnancies, are a far cry from those usually found within the Nigerian education system.

With the conference aiming to make the girls 'better agents for change', the interests of UNICEF and the First Lady's office lie beyond the pageant winner and seek to create a network of peer educators who can tackle young women's problems where formal institutions fail to do so. For the contestants, too, while they undoubtedly focus on the 2 million naira prize money and car (a fact seldom acknowledged during the camp), the conference is regarded as a preparation for life outside pageantry. Where many of the contestants are already involved in NGO work, CCQ is a means for them to develop their passions and to work on respectable ventures. As one contestant recounted: 'The UNICEF part, we loved. I learned stuff I didn't even know. I learned so much.' While societal ills are recognized through a development discourse, the knowledge and skills taught by UNICEF mould respectable and influential women who are aware of and willing to alleviate others' difficulties.

Inspired by the First Lady's prayers, spirituality is paramount - from prayers ending the UNICEF conference and daily 'morning devotion', to girls encouraging each other with the phrase 'Try your best and let God decide the rest'. The camp does much more than just nurture Nigerian religiosity; it explicitly shapes Christian subjectivities. Contestants visit the First Lady's charitable works, demonstrating compassion for women and children by giving donations (such as toilet paper, Indomie noodles, ${ }^{2}$ nappies and money) (see Figure 2). At MACA, with cameras put away to preserve the confidentiality of the refuge, the matron explains the work carried out, identifying God as the refuge's 'ultimate protector'. The contestants are there to inspire the pregnant girls, acting as role models and displaying caring femininity. Yet the visit is also a way of educating contestants about premarital sex. As the matron warned the contestants: 'God has made a man for you; just be patient.'

Christian ideals for single young women go beyond trusting that God's plan for a husband will come to pass, and camp also includes an 'inspirational talk' given by Pastor Imoh, who ministers at a well-regarded Pentecostal church in Calabar. Briefly introducing himself and his wife, he described his life as an accountant and pastor, and explained how God motivates him. The explicit focus on success mirrors the materialism and aspirations picked up on by Marshall (2009) in her analysis of Nigerian Pentecostal millennialism, where the religion will redeem

\footnotetext{
${ }^{2}$ Indomie is an Indonesian brand of noodle. Sold cheaply and being much quicker to cook than rice, or soup and garri, it has become a staple food in Nigeria.
} 


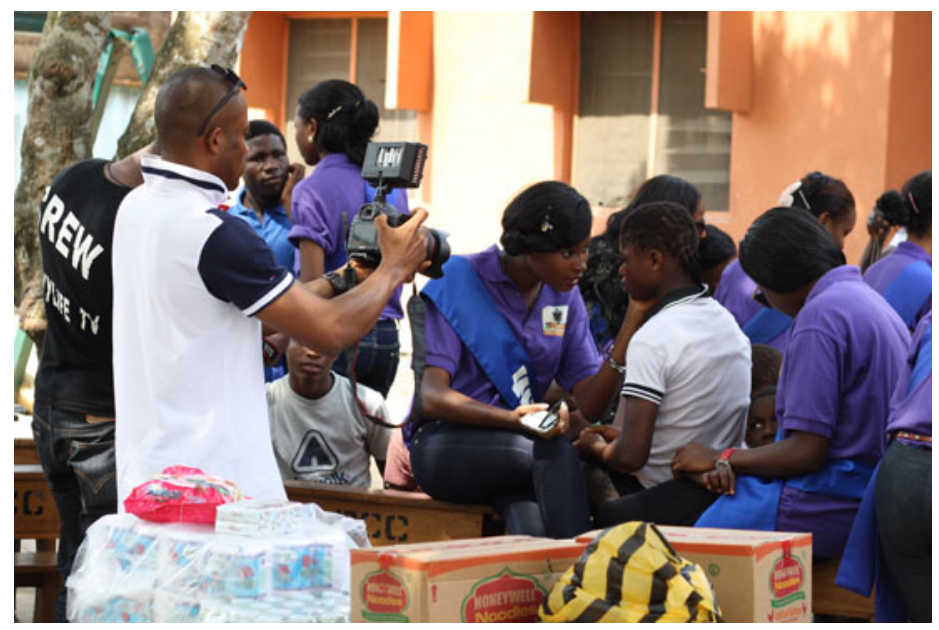

FIGURE 2 Cameras follow the contestants' every move throughout the camp, including their visit to the Destiny's Child Center. The contestants are often moved as they meet the orphaned children cared for by Cross River's First Lady, and frequently their compassion is informed by their own hardships or difficult childhoods.

both the individual and the nation from all iniquity. Pastor Imoh continues his inspirational message with prayers and singing; we are reminded again of Marshall's (2009) argument that triumphant Pentecostal subjects are made through action (cf. Berliner and Sarro 2007; Mahmood 2005). Interestingly, CCQ has had a Muslim contestant (from Kwara State), but while organizers are open to the idea of different faiths attending camp, all contestants must carry out the same activities that are designed for moulding (arguably Pentecostal) Christian femininities.

Contestants also receive etiquette training on 'strategies for effective leadership' and 'emotional intelligence', moulding them 'from the inside'. At a workshop run by two women in business wear, contestants are given scenarios such as hosting a cocktail or dinner party and are expected to set out props correctly and look after pretend guests in an attentive manner. It is notable that the contestants are clueless about these social functions, which are more akin to 'Western' upper-class ideals than Nigerian norms. As most Nigerians eat soup and garri (tapioca) with their hands, it is no surprise that the girls cannot lay a table for a three-course meal. Such etiquette training highlights the importance placed on being 'exposed' and knowing 'outside' Nigeria, and on these attributes being conducive to respectability, social mobility and leadership. However, such training also highlights how beauty pageants shape feminine ideals that do not necessarily correspond to the girls' everyday lives (Sanders and Pink 1996: 59).

While CCQ advocates moral and intellectual feminine beauty, aesthetics are not ignored. Make-up artists practise their art using foundation, colourful eyeshadows, blusher and lip gloss, and nails are manicured in bold colours. With frequent inspections from organizers, the contestants must touch up their own 
make-up throughout the day and are expected to take pride in their appearance. Hair is also professionally styled at the beginning of the camp, with contestants 'fixed' with uniform long, wavy, black 'weave-ons'. Mirroring urban girls' preference for sleek, 'Western'-style hair, length is acknowledged as denoting wealth while the material (real 'Brazilian' or 'Peruvian' versus synthetic) is also a mark of status. Skin colour is also an index of beauty, and Nigerian girls, preferring lighter skin tones, generally try to stay out of the sun, rub in white face powder for protection, and use skin-lightening moisturizing creams. However, while the most 'fair' CCQ contestants may have been greatly admired, they were not necessarily favourites to win unless they also exuded inner 'grace and beauty'. Hence, ideals of beauty appeared to be intricately bound to a performance of certain cultural logics of inner beauty and outward grooming taught throughout the camp.

Dress, too, is a central part of camp life. The contestants are provided with a couple of T-shirts, which they must wash and air in their dormitories. Along with skinny jeans, heels and sashes, girls wear this uniform around camp and on visits. Contestants are sent a list of clothes to buy before camp, detailing different types of high heels and dress styles. This causes contestants much stress, not only because the list can cost up to 100,000 naira but also because products are ever-changing in Nigerian markets. Organizers scrutinize all hemlines, straps and other small details to discern whether they are suitable. Often, girls do not know what constitutes 'corporate wear' and bring something too casual, or are not sure of the difference between 'cocktail dress' and 'evening gown'. In addition, clothes should be figure-hugging but never revealing. It is a constant process of learning what is appropriate and respectable. In an arena where the art of representation is so important for concealing one's background and contributing to the potential of pageantry success, girls must constantly enact these dress codes. Hence, despite the way in which the camp is secluded from the outside world, this 'backstage' area of the contest, with its strict adherence to style and being made up, demonstrates how feminine subjectivities are constantly moulded through performance (Banet-Weiser 1999; cf. Butler 1990).

In its role in providing contestants with 'the final lessons in social life' (Lavendo 1996: 34), CCQ is also integral to inserting contestants into patronage networks. The First Lady aside, the camp is run by influential women associated with the media, Nollywood and government, and former contestants and married women act as chaperones. Camp also provides the girls with the chance to be noticed by dance and modelling instructors, and by international pageant directors who fly in at the last minute from Jamaica. These patronage networks offer potential opportunities and also reaffirm the idea that the knowledge and comportment contestants learn during the camp socialize them, enabling them to re-enter society with a different status (cf. van Gennep 1960). The constant attention to comportment, spirituality and appearance shows how the camp is designed to produce respectable, single, urban women who are linked to other upwardly mobile, educated, charitable, God-fearing and stylish women.

While paying attention to the local, we should also look beyond the ways in which CCQ ties in with other pageants to consider the pageant's cultural continuities with regard to teaching young women how to become respectable feminine subjects in Calabar society. Traditionally, Efik girls, on reaching the age of fourteen or fifteen, would enter seclusion in the 'fattening room' (ufok nkuho) to prepare for womanhood (Akak 1982; Kingsley 1975). Waited upon and given 
advice on womanhood by other women, the girl would be allowed only to eat, sleep and rest. The amount of time in the 'fattening room' was contingent on the family's wealth, with longer periods of seclusion (up to two years) denoting wealthy parents and encouraging higher bride prices. During seclusion, the girl's body would be covered in white chalk (Ndom) and massaged with ground roots to keep the skin soft (Akak 1982). On leaving the 'fattening room' as a 'fattened woman' (Nhuho), and with her bride price completed, the girl would be ready for marriage. Traditionally, this practice was as much an initiation as being about aesthetic beauty. Following the belief that a baby will die if its head touches its mother's uncut clitoris during birth, female circumcision accompanied the mbodi (bride-fattening) process.

With female circumcision now supposedly banned in Cross River, I did not hear of anyone undergoing the mbodi rites. Yet traditional marriage remains highly significant for urban young women in Nigeria, marking a change of status in the community as they leave their father's village and join that of their husband. Female relatives play an important part in this, giving brides advice about marriage in the period leading up to the ceremony. However, it must be noted that young women in Calabar also receive advice about womanhood from outside the family, notably from churches. The Pentecostal church, in particular, puts on special programmes teaching single women to value themselves and know their personal ambitions in preparation for meeting the right partner who will support them, and offers counselling for couples leading up to their 'white wedding'.

New feminine subjects being moulded by Christianity is nothing new in Nigeria (cf. Peel 2000; 2002). Writing about early Igbo Christian converts, Bastian (2000) highlights how the Catholic mission in south-east Nigeria was integral in teaching both Biblical knowledge and domesticity, creating a new class of person. More recently, analyses of African Christianity have picked up on how Pentecostal ministries provide healthcare and advice on relationships and sexuality, allowing young women to take ownership of parts of their lives (Bochow and van Dijk 2012); how Pentecostalism allows young South African women to enjoy financial success without compromising spirituality (Frahm-Arp 2012); and how Brazilian Pentecostalism in Mozambique preaches that young women should take control of their bodies in battling traditional marine spirits (van de Kamp 2011).

With its emphasis on spirituality, success and management of the self, exposure to the world beyond Nigeria, style and materialism, CCQ is also a channel for shaping Pentecostal femininities. Yet what is interesting about CCQ is that the Christian feminine subjects it creates are not admired, respectable and successful in spite of being single but because they are single. Pageantry arguably creates a 'third femininity' in Christian Nigeria: success for the 'small girl' outside marriage. The supposedly chaste winners who preach abstinence conclude their successful reigns having shown caring and God-fearing femininity, not having shown that they are preparing for marriage (ironically, this success earned through singlehood is undoubtedly a longer-term marriage strategy). Hence, as female initiations evolve alongside African societies' aspirations (cf. Ferme 1994; Moore 2011), CCQ replaces more traditional initiation rites and forms of socialization. Just as Moore highlights how the Christian area rehabilitation programmes that replace traditional girls' initiation rites in Marakwet in Kenya take girls out of their usual social setting to 'forge new bonds, identities and 
aspirations' (2011: 48), the CCQ camp is a time when social norms are altered in order to create new social status. Crucially, in the context of African youth's 'crisis of becoming' (cf. Abbink 2005; Honwana 2012), pageantry becomes a viable choice for young women trying to overcome gender and generational marginalization in Nigeria.

\section{'PLATFORMS' AND NETWORKS}

As contestants repeatedly told me, pageantry was a 'platform' for better things. The camp is a place to learn new skills, meet peers and become known by influential people. The prizes - substantial amounts of money, cars, laptops, foreign travel, free clothes - can instantly 'make' the winners and runners-up, and are regarded as investments for the future. It is not uncommon for winners to invest their prize money in businesses (anything from retail to real estate) in order to make more money, and presenting an image of a successful urbanite encourages further success and admiration from others. Where many single young women live in much financial and social insecurity, the stakes for winning are high. As one CCQ organizer recalled about some girls auditioning: 'They are desperate to get out of the situation that they are in.'

These words resonated with many pageant-goers I met in Calabar, who came with divergent experiences and demands of pageantry. For instance, Victoria described herself as a 'bookworm' who, as an only child in a broken home, had a dysfunctional childhood. Feeling unable to relate to others, she entered her first pageant, Miss Teen Cross River, at sixteen in order to overcome her shyness. She came first runner-up, and gained the confidence to enter six other pageants, including CCQ twice. She finally won Miss Biase (her local government area or LGA) in 2010, using the crown to reach out to others like her. Contrasting with Victoria's conscious effort for self-development is Blessing's story of unplanned luck. Coming from a relatively comfortable home, Blessing entered Miss Cross River 2004 to alleviate boredom in Calabar during university holidays. Holding the crown until 2007, she benefited from opportunities to attend youth summits in Kenya and Ghana and to work with well-connected Nigerian women to raise awareness of child trafficking in Yakurr, her LGA. Initially entering for fun, Blessing's was one of the most successful reigns I heard about, giving her management skills that later helped with her own environmental consultancy firm.

Christabel's story is particularly illuminating for understanding the desperation that many young women find themselves in, and from which pageantry appears to be a way out. Entering CCQ - her first pageant - at eighteen, Christabel described herself as 'naïve'. As she spoke of her admiration for the First Lady's projects helping society's marginalized, she mentioned how she herself had felt 'so low' and 'rejected' after her parents' divorce. For Christabel, CCQ was more than a competition; it was 'a dare from the whole world, from my situation ... like, come and try and change me!' She explained this 'dare' a few months later, when she coincidentally joined a popular Pentecostal church in which I had been conducting research. Looking glamorous, with thick, long, brown braids, she appeared more grown-up and sophisticated than the CCQ contestant I had known. 
Three years prior to CCQ, Christabel had relocated to Calabar with her mother and younger siblings. As the eldest daughter, she became responsible for supporting the family while she undertook her university studies. Seeing a poster in the market advertising CCQ, Christabel immediately realized the financial opportunities for her family. Although Christabel did not even reach the top ten, the experience turned out to be more successful than she could have imagined. Following CCQ, she secured lucrative modelling contracts through her Lagos-based agent. Putting her luck down to God's faithfulness, she also explained how pageantry 'just hypes you', elevating her above her fellow aspiring models. Her billboard campaigns for large Nigerian brands paid her a lump sum in the region of 500,000 naira, easily covering her family's rent for two years.

As she described how she became able to support her family, it transpired that this had not always been the case. Before CCQ, Christabel had dated one of Calabar's most eligible bachelors for a couple of years. Justifying this, she said: 'I just needed someone very old and rich - I was very young and penniless!' Speaking proudly of her newfound independence from the man's finances and demands, she stated how she wanted to work hard and have her own money so that men would respect her. Hence, Christabel's story not only depicts the great burdens of responsibility that many young women endure, but also highlights the complexities of exchange, dependence and respect inherent in young women's relationships with men. As Christabel's billboards show, pageantry gives young women an identity, enabling them to get jobs through the performance of an admired female beauty.

While Christabel's story highlights how pageantry can be an enabling experience, young women acknowledge that the winner's title is the most attractive and lucrative part of pageantry, opening doors to seemingly infinite opportunities. Contestants viewed being a 'Miss' as making it easier to ask others to patronize their businesses or charitable ventures, as well as making visa applications more successful. Yet, young women view this 'platform', the social elevation that pageantry facilitates, not only as a means of extracting themselves from current difficulties but also as a place where they can have a voice and be recognized. The experience of Nikita is another good example of how young women view winning as a step up from their current situation and towards the realization of their aspirations. As Nikita explained:

When I sat down as Miss UniCal, I said, 'I can't just sit here and do nothing!' Being Miss University of Calabar - there is so much money inside that place! I have to get my own share and do something ... Funnily enough, the university has been there since 1975, and I was so surprised to hear that a queen will sit as Miss UniCal without a letterhead. No letterhead! And I was like, how was she corresponding with the world? With the school community and all of that? So, the first thing I did was, I had my letterhead ... I now wrote to school about it - 'I want to do this and this.' The VC [vice chancellor] was surprised. He had to comment, 'There is no project in school for anything to be done by Miss UniCal.' I said, 'I'm here o! And I want to do something about it, so you must hear me out!'

As Nikita described how UniCal's vice chancellor did eventually give her money to carry out charitable projects, she reiterated the salient idea of patronage and care constituting feminine respectability in Calabar. Yet she also illustrated how 
queens not only milk the system for what they can get but also must work hard to gain respect. Nikita went on: 'The thing about Nigerian pageants, even if they don't package it well, when you sit on the throne, you can actually do something better with it.' With aspirations for going into politics, Nikita viewed pageantry as a 'platform for something higher'. Speaking of her crown, she said: 'It really helps to get focused. To me, it's like you make good use of it.'

After winning Miss UniCal 2009, Nikita was automatically entered for Miss University Nigeria the same year. She came second runner-up, gaining confidence to aim for more prestigious pageants in 2010. She was unplaced in CCQ but came first runner-up in Miss Niger Delta. Re-entering the following year, she won the Miss Niger Delta 2011 crown. The camp was more fun and the prizes bigger (a car, an allowance, an all-expenses trip anywhere in the world), and the Miss Niger Delta pageant also inserted Nikita into more influential patronage networks. Nodding towards her mobile phone, she explained how she could easily call any of the Delta's nine state governors - no longer was she dealing just with university peers. Yet Nikita appeared more taken with the network of former Miss Niger Deltas that she had joined. Able to chat to the former queens on a private BlackBerry Messenger group they had set up, Nikita joined a community offering friendship and advice for her reign. Hence, while pageantry does enable young women to enter existing patronage networks, it is important to point out that Nigeria's enthusiasm for beauty pageants is creating new networks of young women with the contacts and comportment to become increasingly influential in their own right.

Unfortunately, contestants' high hopes of the rewards of being a 'Miss' were given the lie by former queens' complaints of how the 'package' they received was not as advertised: trips abroad were postponed or destinations changed (sometimes due to visa issues), and monthly instalments of prize money were either greatly reduced or non-existent. While Nikita had spoken enthusiastically about pageantry, our conversation was littered with references to her prize car, which she never saw again after the contest night. Her understanding was that it remained parked in Bayelsa State until someone paid their share of the pageant expenses, exemplifying the mixture of disappointment and the will to keep trying that so many contestants have in response to pageantry.

Noela, another experienced pageant-goer, explained that the prospect of failure ought not to be a factor dissuading young women from participating. 'You can't say that they won't give it to me so I won't go. Most people don't just enter a pageant for the prize ... they want to see if doors of opportunity will open for them.' Coming runner-up in Imo State's Miss Heartland 2008, Noela went on to contest for Miss African Queen, her university's Miss Campus, and finally CCQ 2009. Although not all her prizes had materialized, when I met the twenty-three-year-old theatre arts graduate in 2012 she explained enthusiastically how, despite the pitfalls of entering 'fake pageants', the contacts and status she gained through the contests had helped her establish her own movie production firm. Such failures and disappointments in the pageantry world speak directly to analyses of the corruption, duplicity and illusion pervading Nigerian life (cf. Apter 1999; 2005; Smith 2007). Crowns do not always remove young women from the mercies of fraud and fakery. Yet the lack of regulation also gives contestants hope for other possibilities. 
As with missing prizes, winners' experiences were often very different from contestants' beliefs that a crown creates an instant platform for respect and authority. Queens are expected to raise funds for pet projects, and must write proposals and visit businessmen. They are often asked for sexual favours in order to have a chance of receiving patronage. While Christabel maintained that pageantry emancipated her from a controlling relationship, Nikita wearily explained: 'People think [queens] have it all rosy ... They don't know the challenges we are facing. The major thing that faces us is that men want to sleep with us ... All they want to do is sleep with you. All they want to do.' Of course, these 'challenges' continue because some young women do use men to win pageants - scandals of winners' associations with 'big men' are neither uncommon nor shocking to Nigerians. For instance, explaining how she stepped on toes as she tried to collect money for Miss Cross River's charitable projects, Blessing recounted: 'I was turning these men down and making them see that this was not what the pageant was about ... And a lot of queens were doing these things. They were dating people in government.' Unwilling to 'compromise' themselves, many queens become frustrated when projects and prizes are stalled.

It is questionable whether queens are just as disempowered as the young women their charitable projects target. While they were disappointed by men's advances and the failure of prizes to materialize, this was also considered just the way things worked in Nigeria. Significantly, queens viewed their ability to say 'no' and to play the 'enduring' woman, knowing they had other options, as the thing that differentiated them from more marginalized women. Inasmuch as young women consider winning a crown as being given a voice, despite not being respected as equals by men, the case of Nigerian beauty queens adds to those accounts questioning our understanding of female empowerment through gender equality (Mahmood 2005; Mate 2002; Soothill 2007). As Banet-Weiser (1999) suggests, focusing on the contestants is important for debunking the idea that they are in the grip of false consciousness. The cases discussed here highlight the different motivations, expectations and experiences of Nigerian pageant-goers. Despite girls' experiences being far from uniform, their voices highlight how pageantry is a site in which new feminine subjectivities can be formed: regardless of the 'challenges', winners must keep performing the caring, stylish, God-fearing woman if they are to retain influence and respectability.

\section{CONCLUSION}

By developing an analysis of beauty pageants as sites for reifying communities' ideals of femininity, this paper has discussed how pageantry creates an avenue for young women to gain respect and admiration in Nigerian society through the performance of a specific ideal. Building upon Banet-Weiser's (1999) analytical focus on performance of the gendered body to highlight contestants' agency, the discussion has complicated ideas that pageant-goers can completely overturn male dominance. While young women want to emulate the successes of First Ladies by performing the role of the caring, God-fearing, well-connected and stylish female, the discussion has shown that this constant performance of feminine respectability supports rather than counters patriarchy in Nigeria. As such, the discussion has added to other analyses exploring women's lived 
experiences of patriarchy (for example, Abu-Lughod 1986; 1989; Mahmood 2005; Soothill 2007).

While focusing on the creation of caring, God-fearing and respectable femininities, the discussion has also raised interesting questions about young women's relationship to wider society. Young women have various reasons for entering pageants, but their recognition of the longer-term success accrued through performing the role of the charitable female contributes to broader analyses of how youth in Africa are trying to overcome the difficulties of 'growing up' (cf. Honwana 2012). Pageants such as CCQ are not only replacing more 'traditional' gendered initiations marking new life stages but are also sites in which new Christian subjects can be actively moulded outside the church. Above all, beauty queens articulate changing ideas of feminine respectability in Christian Nigeria, where the creation of a 'third femininity' means that 'small girls' are able to gain some authority in society without (yet) being married. Leading on from this, the paper has shown how pageantry has become a means for Nigerians to counter the insecurities that pervade their livelihoods: the queen becomes hope for the nation. The contestant who was asked on the CCQ contest night which judge she would save from the burning building gave the correct answer: the former Carnival Calabar Queen, because she will go on to do good work for Nigeria.

\section{ACKNOWLEDGEMENTS}

This work was supported by an ESRC Studentship (grant number ES/I903887/1). I would also like to thank Ms Enuma Chigbo for all her time and support with my research on CCQ.

\section{REFERENCES}

Abbink, J. (2005) 'Being young in Africa: the politics of despair and renewal' in J. Abbink and I. van Kessel (eds), Vanguard or Vandals: youth, politics and conflict in Africa. Leiden: Brill.

Abu-Lughod, L. (1986) Veiled Sentiments: honor and poetry in a Bedouin society. Berkeley CA and London: University of California Press.

- (1989) 'The romance of resistance: tracing transformations of power through Bedouin women', American Ethnologist 17 (1): 41-55.

Akak, E. O. (1982) Efiks of Old Calabar. Volume III: culture and superstitions. Calabar, Nigeria: Akak and Sons.

Amadiume, I. (1987) Male Daughters, Female Husbands: gender and sex in an African society. London: Zed Books.

Apter, A. (1999) 'IBB=419: Nigerian democracy and the politics of illusion' in J. Comaroff and J. L. Comaroff (eds), Civil Society and the Political Imagination in Africa: critical perspectives. London: University of Chicago Press.

- (2005) The Pan-African Nation: oil and the spectacle of culture in Nigeria. Chicago IL and London: University of Chicago Press.

Banet-Weiser, S. (1999) The Most Beautiful Girl in the World: beauty pageants and national identity. Berkeley CA and London: University of California Press. 
Bastian, M. L. (2000) 'Young converts: Christian missions, gender and youth in Onitsha, Nigeria 1880-1929', Anthropological Quarterly 73 (3): 145-58.

Berliner, D. and R. Sarro (2007) 'On learning religion: an introduction' in D. Berliner and R. Sarro (eds), Learning Religion: anthropological approaches. New York NY and Oxford: Berghahn Books.

Bochow, A. and R. van Dijk (2012) 'Christian creations of new spaces of sexuality, reproduction, and relationships in Africa: exploring faith and religious heterotopia', Journal of Religion in Africa 42: 325-44.

Boddy, J. (1989) Wombs and Alien Spirits: women, men, and the zar cult in northern Sudan. Madison WI: University of Wisconsin Press.

Butler, J. (1990) Gender Trouble: feminism and the subversion of identity. New York NY and London: Routledge.

Chabal, P. and J. Daloz (1999) Africa Works: disorder as political instrument. Oxford and Bloomington IN: James Currey and Indiana University Press.

Chazan, N. (1989) 'Gender perspectives on African states' in J. L. Parpart and K. A. Staudt (eds), Women and the State in Africa. Boulder CO: Lynne Rienner.

Cohen, C. B., R. Wilk and B. Stoeltje (1996) 'Introduction' in C. B. Cohen, R. Wilk and B. Stoeltje (eds), Beauty Queens on the Global Stage: gender, contests and power. New York NY and London: Routledge.

Douglas, S. (1994) Where the Girls Are. Berkeley CA: University of California Press.

Ferme, M. (1994) 'What "Alhaji Airplane" saw in Mecca, and what happened when he came home: ritual transformation in a Mende community (Sierra Leone)' in C. Stewart and R. Shaw (eds), Syncretism/Anti-syncretism: the politics of religious synthesis. London: Routledge.

Foucault, M. (1998) The History of Sexuality: the will to knowledge. Volume 1. London: Penguin.

Frahm-Arp, M. (2012) 'Singleness, sexuality, and dream in marriage', Journal of Religion in Africa 42: 369-83.

Haram, L. and C. B. Yamba (eds) (2009) Dealing with Uncertainty in Contemporary African Lives. Uppsala: Nordiska Afrikainstitutet.

Honwana, A. (2012) The Time of Youth: work, social change, and politics in Africa. Sterling VA: Kumarian Press.

James, D. (2002) "To take the information down to the people": life skills and HIV/AIDS peer-educators in the Durban area', African Studies 61 (1): 169-91.

Kingsley, M. (1975) 'Calabar: the fattening house' in T. Hodgkin (ed.), Nigerian Perspectives: an historical anthology. London: University of London Press.

Lavendo, R. H. (1996) “'It's not a beauty pageant!”: hybrid ideology in Minnesota community queen pageants' in C. B. Cohen, R. Wilk and B. Stoeltje (eds), Beauty Queens on the Global Stage: gender, contests and power. New York NY and London: Routledge.

Mahmood, S. (2005) Politics of Piety: the Islamic revival and the feminist subject. Princeton NJ and Oxford: Princeton University Press.

Mama, A. (1995) 'Feminism or femocracy? State feminism and democratisation in Nigeria', Africa Development XX (1): 37-58.

Marshall, R. (2009) Political Spiritualities: the Pentecostal revolution in Nigeria. Chicago IL and London: University of Chicago Press.

Mate, R. (2002) 'Wombs as God's laboratories: Pentecostal discourses of femininity in Zimbabwe', Africa 72 (4): 549-68. 
Mbembe, A. (2001) On the Postcolony. Berkeley and Los Angeles CA: University of California Press.

McNeill, F. (2011) AIDS, Politics and Music in South Africa. Cambridge: Cambridge University Press for the International African Institute.

Mercer, C. (2014) 'Middle class construction: domestic architecture, aesthetics and anxieties in Tanzania', Journal of Modern African Studies 52 (2): 227-50.

Moore, H. L. (2011) Still Life: hopes, desires and satisfactions. Cambridge: Polity.

Moskalenko, L. (1996) 'Beauty, women, and competition: "Moscow beauty 1989"' in C. B. Cohen, R. Wilk and B. Stoeltje (eds), Beauty Queens on the Global Stage: gender, contests and power. New York NY and London: Routledge.

Ncube, M., C. L. Lufumpa and S. Kayizzi-Mugerwa (2011) The Middle of the Pyramid: dynamics of the middle class in Africa. Abidjan: African Development Bank.

Obadare, E. and W. Adebanwi (2010) Encountering the Nigerian State. Basingstoke: Palgrave Macmillan.

Peel, J. D. Y. (2000) Religious Encounter and the Making of the Yoruba. Bloomington IN: Indiana University Press.

- (2002) 'Gender in Yoruba religious change', Journal of Religion in Africa 32 (2): $136-66$.

Sanders, R. and S. Pink (1996) 'Homage to "La Cordobesa": local identity and pageantry in Andalusia' in C. B. Cohen, R. Wilk and B. Stoeltje (eds), Beauty Queens on the Global Stage: gender, contests and power. New York NY and London: Routledge.

Schulz, D. (2000) 'Mesmerising "missis", nationalist musings: beauty pageants and the public controversy over "Malian womanhood", Paideuma 46: 111-35.

Smith, D. J. (2007) A Culture of Corruption: everyday deception and popular discontent in Nigeria. Princeton NJ and Oxford: Princeton University Press.

Soothill, J. E. (2007) Gender, Social Change and Spiritual Power: charismatic Christianity in Ghana. Leiden and Boston MA: Brill.

van de Kamp, L. (2011) 'Converting the spirit spouse: the violent transformation of the Pentecostal female body in Maputo, Mozambique', Ethnos: Journal of Anthropology 76 (4): 510-33.

van Gennep, A. (1960) The Rites of Passage. Chicago IL: University of Chicago Press.

Watson, E. and D. Martin (2004) 'There She Is, Miss America': the politics of sex, beauty, and race in America's most famous pageant. New York NY: Palgrave Macmillan.

Yarrow, T. (2011) Development Beyond Politics: aid, activism and NGOs in Ghana. Basingstoke: Palgrave Macmillan.

\section{ABSTRACT}

Beauty pageants in Nigeria have become highly popular spectacles, the crowned winners venerated for their beauty, success and ability to better society through charity. This paper focuses on the Carnival Calabar Queen pageant, highlighting how pageants, at the nexus of gender and the nation, are sites of social reproduction by creating feminine ideals. A divinely inspired initiative of a fervently Pentecostal First Lady, the pageant crowns an ambassador for young women's 
rights. While the queen must have 'grace and beauty' and be 'ever prayerful', the discussion unravels emic conceptions of feminine beauty, religiosity and respectability. Yet, young women also use pageantry as a 'platform' for success, hoping to challenge the double bind of gender and generation they experience in Nigeria. The discussion pays particular attention to how young women, trying to overcome the insecurities of (urban) Nigerian life, make choices to negotiate individualism with community, and piety with patriarchy. Ethnographically, this paper situates beauty pageants in the region's past and present practices that mould feminine subjectivities. Contributing young women's experiences to recent literature on the temporalities of African youth, the paper's explicit focus on how new subjectivities form through action illuminates important themes regarding agency, resistance and notions of the religious self. In doing so, it furthers current analyses of Pentecostalism, seeking a more nuanced understanding of gender reconfiguration and demonstrating how religious subjects can be formed outside church institutions.

\section{RÉSUMÉ}

Au Nigeria, les concours de beauté sont devenus des spectacles très populaires dont les candidates couronnées sont vénérées pour leur beauté, leur succès et leur capacité à rendre la société meilleure par des actions caritatives. À travers l'élection de la Reine du Carnaval de Calabar, l'article montre que les concours de beauté, à la liaison entre le genre et la nation, sont des lieux de reproduction sociale en créant des idéaux féminins. Cette élection, divinement inspirée à l'initiative d'une Première dame pentecôtiste fervente, couronne une ambassadrice des droits des femmes jeunes. Alors que la Reine doit posséder "grâce et beauté » et rester " concentrée dans la prière », la discussion dévoile des conceptions émiques de la beauté féminine, de la religiosité et de la respectabilité. Pourtant, les jeunes femmes utilisent également les concours de beauté comme un tremplin vers le succès, dans l'espoir de relever le double défi que représentent pour elles le genre et la génération au Nigeria. La discussion prête une attention particulière à la manière dont les jeunes femmes, dans leur tentative de surmonter les insécurités de la vie (urbaine) au Nigeria, font des choix pour négocier entre individualisme et communauté, et entre piété et système patriarcal. Sur le plan ethnographique, cet article situe les concours de beauté dans les pratiques passées et présentes de la région qui façonnent les subjectivités féminines. En contribuant les expériences de ces jeunes femmes à la littérature récente sur les temporalités de la jeunesse africaine, l'accent explicite de l'article sur le mode de formation de nouvelles subjectivités à travers l'action met en lumière des thèmes importants concernant l'action, la résistance et les notions du soi religieux. Ce faisant, il fait progresser les analyses actuelles du pentecôtisme, en recherchant une compréhension plus nuancée de la reconfiguration des genres et en démontrant comment des thèmes religieux peuvent se former en dehors des institutions de l'Église. 